\title{
Senna alata leaves are a good source of propelargonidins
}

Article

Accepted Version

Ramsay, A. and Mueller-Harvey, I. (2016) Senna alata leaves are a good source of propelargonidins. Natural Product Research, 30 (13). pp. 1548-1551. ISSN 1478-6419 doi: https://doi.org/10.1080/14786419.2015.1108976 Available at https://centaur.reading.ac.uk/41864/

It is advisable to refer to the publisher's version if you intend to cite from the work. See Guidance on citing.

To link to this article DOI: http://dx.doi.org/10.1080/14786419.2015.1108976

Publisher: Taylor \& Francis

All outputs in CentAUR are protected by Intellectual Property Rights law, including copyright law. Copyright and IPR is retained by the creators or other copyright holders. Terms and conditions for use of this material are defined in the End User Agreement.

\section{www.reading.ac.uk/centaur}

\section{CentAUR}

Central Archive at the University of Reading

Reading's research outputs online 


\section{Senna alata leaves are a good source of propelargonidins}

Aina Ramsay $^{\text {¿ }}$, Irene Mueller-Harvey ${ }^{\mathrm{a}}$

${ }^{a}$ Chemistry and Biochemistry Laboratory, School of Agriculture, Policy and

Development, University of Reading, 1 Earley Gate, P O Box 236, Reading RG6 6AT,

U.K

^Corresponding author: aina.ramsay@hotmail.fr 


\section{Senna alata leaves are a good source of propelargonidins}

Proanthocyanidins (PA) in Senna alata leaves were investigated by thiolysis with benzyl mercaptan, LC-MS and NMR and consisted of rare, but almost pure propelargonidins with $<6 \%$ procyanidins, had B-type linkages a mean degree of polymerisation of 3. Epiafzelechin was the major flavan-3-ol subunit (>94\%) and epicatechin a minor constituent (6.4\%) in residual PA and mainly detected as an extension unit.

Keywords: Senna alata, Cassia alata, proanthocyanidins, propelargonidins, LCMS, NMR, thiolysis

\section{Introduction}

Senna alata (L.) Roxb grows in Central America, Africa and the Caribbean area. The leaves are traditionally used as decoctions for dermatological applications (skin rashes, shingles (Herpes zoster), eczema, mycosis) and against constipation (Hennebelle et al. 2009). S. alata has exhibited antibacterial, antifungal, anti-diabetic and anti-inflammatory activities (Hennebelle et al. 2009; Sagnia et al. 2014). Apart from a few reports on flavonoids and anthraquinones, there is little information on their proanthocyanidin (PA) composition (Abii \& Onuha 2014, Hennebelle et al. 2009), which is being reported in full here for the first time.

\section{Results and discussion}

\subsection{Characterisation and flavan-3-ol composition of PA in S. alata}

\subsubsection{Analysis by thiolytic degradation}

S. alata leaves were subjected to thiolysis to determine PA content and composition. Terminal and extension flavan-3-ol units within PA were analysed by HPLC-ESI-MS (see Supplementary) and PA content and composition are described in Table 1. Figure S2 illustrates the HPLC chromatogram of the thiolysis reaction applied directly to S. alata leaves. Several other phenolic compounds were also detected and assigned according to the literature (Table S1). The PA content was $2.5 \mathrm{~g} / 100 \mathrm{~g}$ of dry weight (DW) and the mean degree of polymerisation $(\mathrm{mDP})$ of the PA was 3 . These PA were almost pure propelargonidins that consisted of epiafzelechin (EAz) (Figure S1, Figure S2, Table 1). Epiafzelechin was assigned to peak 3 at 29.3 min and generated fragment ions at $m / z 309.3[\mathrm{M}-\mathrm{H}]^{-} \mathrm{Cl}^{-}$and $m / z 273.3[\mathrm{M}-$ $\mathrm{H}]^{-}$. The epiafzelechin-BM adduct was assigned to peak 7 at 44.9 min and generated fragment ions at $\mathrm{m} / \mathrm{z} 431.3[\mathrm{M}-\mathrm{H}]^{-} \mathrm{Cl}^{-}, \mathrm{m} / z 395.3[\mathrm{M}-\mathrm{H}]^{-}$and after loss of the benzyl mercaptan molecule (- $124 \mathrm{amu})$ at $\mathrm{m} / \mathrm{z}$ 271.2. Extractable PA (ePA) were analysed in the aqueous acetone extract and unextractable PA (uPA) in the plant residue after extraction. More ePA than uPA 
were found (1.7 vs $0.7 \mathrm{~g} / 100 \mathrm{~g} \mathrm{DW}$ ), but residual uPA had a slightly larger mDP-value (4.4 vs 3.4). Extraction removes impurities and can concentrate PA in the extract and residue; this appeared to facilitate a more sensitive PA analysis. As a result, low proportions of epicatechin were detected as extension units in ePA and uPA, although this was not detected during direct PA analysis of whole leaves. Slightly more epicatechin was detected in extension units of uPA than ePA (6.4 vs $2.4 \%$ ) (fragment ions at $m / z 447.3[\mathrm{M}-\mathrm{H}]^{-} \mathrm{Cl}^{-}, m / z 411.3[\mathrm{M}-\mathrm{H}]^{-}$and after loss of the benzyl mercaptan molecule $(-124 \mathrm{amu})$ at $m / z$ 287.3). Sephadex ${ }^{\mathrm{TM}} \mathrm{LH}-20$ was used to purify the PA from the extract to confirm this PA characterisation and yielded two fractions. The F1-fraction had $34 \mathrm{~g} \mathrm{PA} / 100 \mathrm{~g}$ fraction and F2-fraction had $50 \mathrm{~g} \mathrm{PA} / 100 \mathrm{~g}$ fraction. PA in the F1-fraction contained only EAz and no epicatechin, but PA in the F2-fraction were slightly larger (mDP 6.4 vs 2) and epicatechin was detected as an extension unit (Figure S3).

\subsubsection{NMR analysis of F2-fraction}

The F2-fraction was subjected to NMR analysis-and the ${ }^{1} \mathrm{H}-{ }^{13} \mathrm{C}$ HSQC spectrum clearly shows the presence of PP (Figure S1, Figure S4): signals at $6.7 \mathrm{ppm}$ and $7.3 \mathrm{ppm}$ were assigned to $\mathrm{H} / \mathrm{C}-3^{\prime} / 5^{\prime}$ (PP) and to $\mathrm{H} / \mathrm{C}-2^{\prime} / 6$ ' (PP), respectively. The signal at $4.7 \mathrm{ppm}$ was assigned to $\mathrm{H} / \mathrm{C}-4$ and at $6.00 \mathrm{ppm}$ to $\mathrm{H} / \mathrm{C}-6$ and $\mathrm{H} / \mathrm{C}-8$; which confirms that $S$. alata PA contains B-type linkages between $\mathrm{C}_{4} \rightarrow \mathrm{C}_{8}$ (Appeldoorn et al. 2009). The signal at $5.1 \mathrm{ppm}$ was assigned to H/C-2; and signals at 3.8 and $4.2 \mathrm{ppm}$ to H/C-3. More than one signal was detected for H/C-3 and could be due to the cis/trans configurations at the C-ring (Foo et al. 2000). The same results are also visible in the ${ }^{13} \mathrm{C}$-spectrum (Figure S5). Signals at $112.8 \mathrm{ppm}\left(\mathrm{C}-3^{\prime} / 5^{\prime}\right)$, $125.4 \mathrm{ppm}\left(\mathrm{C}-2^{\prime} / 6^{\prime}\right)$ and $157.1 \mathrm{ppm}\left(\mathrm{C} 4^{\prime}\right)$ belong to PP subunits. C-4, C-6, C-10 and C-8 were identified at 35.3, 96.2, 103.2 and $106.6 \mathrm{ppm}$ as well as $\mathrm{C}-1^{\prime}$ ' at $130 \mathrm{ppm}$ and C-5/7/9 at 154.8 ppm. Signals at 65.0 and $72.1 \mathrm{ppm}$ were attributed to terminal and extension units of cis and trans-flavan-3-ols for C-3. The signal at $76.7 \mathrm{ppm}$ corresponds to C-2 from an extension unit (cis). The predominance of this signal over the C-3 signals from extension unit (cis + trans) strongly suggests that the stereochemistry of the PP subunit is mainly cis and confirms the thiolysis results and the epi-configuration. Moreover, no signal corresponding to a trans extension unit for $\mathrm{C}-2$ was detected.

It remains to be seen whether the presence of these PP can account for the fact that $S$. alata leaves are used for skin treatments in traditional medicine: PP have a low hydroxylation pattern (just $1 \mathrm{OH}$-group in the B-ring, Figure 1) compared to procyanidins (PC, 2 groups) or prodelphinidins (PD, 3 groups). Dobreva (2012) showed that PC had lower affinities and enthalpies during PA-protein binding than PD. Therefore, PP can be expected to bind less strongly to skin proteins than most other PA, but the implications of this hypothesis will need further research. To conclude, plants with pure PP are relatively rare (Falleh et al. 2011, Van 
Huynh \& Bevington 2014) and S. alata leaves are a useful source of PP for research into their biological activities compared to other PA.

\section{Funding}

The European Commission (Marie Curie Initial Training Network, Grant PITN-GA2011-289377, LegumePlus) supported this work. The authors thank C. Drake, H. Ropiak and C. Fryganas for laboratory support and Mrs Anita Bazir for the plant samples.

\section{References}

Abii TA, Onuha EN. 2014. A preliminary investigation into the phytochemicals, vitamins and mineral constituents of the leaf of two tradomedicinal plants - Urena lobata and Cassia alata used in Nigeria. IOSR-JAC. 7:1-4

Appeldoorn MM, Sanders M, Vincken JP, Cheynier V, Le Guernevé C, Hollman PCH, Gruppen H. 2009. Efficient isolation of major procyanidin A-type dimers from peanut skins and B-type dimers from grape seeds. Food Chemistry 117:713-720.

Dobreva MA 2012. Biophysical characterisation of the interaction of sainfoin and other tannins with proteins. PhD thesis, University of Reading, UK.

Falleh H, Oueslati S, Guyot S, Ben Dali A, Magné C, Abdelly C, Ksouri R. 2011. LC/ESIMS/MS characterisation of procyanidins and propelargonidins responsible for the strong antioxidant activity of the edible halophyte Mesembryanthemum edule L. Food Chem. 127:1732-1738.

Foo LY, Lu YOP, Molan AL, Woodfield DR, McNabb WC. 2000. The phenols and prodelphinidins of white clover flowers. Phytochemistry. 54:539-548.

Hazni H, Ahmad N, Hitotsuyanagi Y, Takeya K, Choo CY. 2008. Phytochemical constituents from Cassia alata with inhibition against methicillin-resistant Staphylococcus aureus (MRSA). Planta Med. 74: 1802-1805.

Hennebelle T, Weniger B, Joseph H, Sahpaz S, Bailleul F. 2009. Senna alata. Fitoterapia. 80: 385-393.

Martin TS, Ohtani K, Kasai R, Yamasaki K. 1998. Phenolic compounds from leaves of Cassia alata. Nat. Med. 52: 373-379.

Moriyama H, lizuka T, Nagai M, Murata Y. 2003. HPLC quantification of kaempferol-3-Ogentiobioside in Cassia alata. Fitoterapia 74:425-430.

Rahaman MS, Moynul Hasan AJM, Ali MY, Ali MU. 2006. A flavone from the leaves of Cassia alata. Bangladesh J. Sci. Ind. Res. 41:93-96.

Sagnia B, Fedeli D, Casetti R, Montesano C, Falcioni G, Colizzi V. 2014. Antioxidant and antiinflammatory activities of extracts from Cassia alata, Eleusine indica, Eremomastax speciosa, Carica papaya and Polyscias fulva medicinal plants collected in Cameroon. PLoS ONE. 9:1-10.

Smith RM, Ali S. 1979. Anthraquinone form the leaves of Cassia alata from Fiji. N. Z. J. Sci. 22:123-125.

Van Huynh A, Bevington J. 2014. MALDI-TOF MS Analysis of proanthocyanidins in two lowland tropical forest species of Cecropia: A first look at their chemical structures. Molecules. 19:14484-14495. 
Table 1. Total, extractable, unextractable and purified fractions of proanthocyanidins (PA) from S. alata leaves in terms of PA content (g PA/100 $\mathrm{g} \mathrm{DW}$ ), mean degree of polymerisation (mDP), percentages (\%) of propelargonidins (PP), procyanidins (PC), and cis-flavan-3-ols. The flavan-3ol composition of PA in terminal and extension units is shown separately (percentages are relative molar percentages; SD in parentheses; $\mathrm{n}=3$ ).

\begin{tabular}{llllll||lll}
\hline & & & & & & Terminal unit & \multicolumn{2}{l}{ Extension unit } \\
\hline & PA & $\mathrm{mDP}$ & $\% \mathrm{PP}$ & $\%$ PC & \% cis & EAz & EC & EAz \\
\hline Total PA & $2.5(0.1)$ & $3.4(0.1)$ & $100(0)$ & $0(0)$ & $100(0)$ & $29.6(0.4)$ & $0.0(0.0)$ & $70.5(0.1)$ \\
Extractable PA & $1.7(0.1)$ & $3.1(0.1)$ & $97.7(0.1)$ & $2.4(0.1)$ & $100(0)$ & $24.6(0.4)$ & $2.3(0.1)$ & $73.1(0.5)$ \\
Unextractable PA & $0.7(0.1)$ & $4.4(0.1)$ & $93.7(0.6)$ & $6.4(0.6)$ & $100(0)$ & $22.6(0.1)$ & $6.4(0.0)$ & $71.1(0.1)$ \\
F1-fraction & $34.1(1.1)$ & $2.0(0.1)$ & $100(0)$ & $0(0)$ & $100(0)$ & $33.9(0.1)$ & $0.0(0.0)$ & $66.1(0.2)$ \\
F2-fraction & $50.4(0.1)$ & $6.4(0.1)$ & $98(0)$ & $2(0)$ & $100(0)$ & $13.5(0.1)$ & $1.9(0.1)$ & $84.7(0.1)$ \\
\hline
\end{tabular}

